Düzeltme - Erratum

\title{
Atık Tavuk Tüyünün Zemin İyileştirmesinde Değerlendirilmesi
}

Burak Görgün $^{1 *}$, Ertaş Bozkurt ${ }^{2}$, Duygu Kuru ${ }^{3}$, Alev Akpınar Borazan ${ }^{4}$, Nazile Ural ${ }^{5}$ 
Düzeltme - Erratum

\title{
Atık Tavuk Tüyünün Zemin İyileștirmesinde Değerlendirilmesi
}

\author{
Burak Görgün $^{1 *}$, Ertaş Bozkurt ${ }^{2}$, Duygu Kuru$^{3}$, Alev Akpınar Borazan ${ }^{4}$, Nazile Ural $^{5}$ \\ Geliş / Received: 29/11/2018 \\ Revize / Revised: $24 / 12 / 2018$ \\ Kabul / Accepted: 14/12/2018
}

\begin{abstract}
$\overline{\mathbf{O Z Z}}$
Bu çalışmanın amacı, tavuk kesim tesislerinde ortaya çıkan atık tavuk tüyünün siltli zeminlerin iyileştirilmesinde katkı malzemesi olarak kullanılıp kullanılamayacağının araştırılmasıdır. Zayıf temel zeminlerinde karşılaşılan yetersiz taşıma gücü ve yüksek deformasyon sorunları temel zeminini iyileştirme konusunda yeni yöntemlerin geliştirilmesini ve uygulamasını gerekli kılmaktadır. Mekanik iyileştirmenin yeterli olmadığı veya kullanılamadığı durumlarda kimyasal iyileştirme veya atıkların kullanılması bir alternatif olarak karşımıza çıkmaktadır. Bu çalışmada, silte $\% 1$ ve $\% 3$ oranlarında toz atık tavuk tüyü, kesilmiş atık tavuk tüyü ve tam atık tavuk tüyü olacak şekilde tavuk tüyleri eklenerek karışımlar hazırlanmış ve standart kompaksiyon deneyi ile hazırlanan numuneler üzerinde serbest basınç deneyi uygulanmıștır. Çalıșma sonucunda, atık tavuk tüyünün pahalı liflere alternatif potansiyel malzeme olabileceği fakat daha farklı boyutta, farklı oranlarda ve farklı katkı malzemeleriyle deney sayısının arttırılmasının gerekli olduğu görülmüştür.
\end{abstract}

Anahtar Kelimeler-Silt, Atık Tavuk Tüyü, Standart Kompaksiyon, Serbest Basınç Deneyi, Mikroyapı

\footnotetext{
1*Sorumlu yazar iletişim: burak.gorgun@bilecik.edu.tr (https://orcid.org/ 0000-0002-7681-863X) Inşaat Mühendisliği Bölümü, Mühendislik Fakültesi Bilecik Şeyh Edebali Üniversitesi, Bilecik 2İletişim: ertaccbozkurt@gmail.com (https://orcid.org/0000-0001-7715-9907) Bölüm Adl, Üniversite Adl, Adres veya İkinci Şirket İsmi, Şirket İsmini de İçeren Adres Bilgisi 3̇letişim: duygu.gokdai@bilecik.edu.tr (https://orcid.org/ 0000-0002-9727-5785) Kimya Mühendisliği Bölümü, Mühendislik Fakültesi Bilecik Șeyh Edebali Üniversitesi, Bilecik 4İletişim: alev.akpinar@bilecik.edu.tr (https://orcid.org/ 0000-0002-3815-2101) Kimya Mühendisliği Bölümü, Mühendislik Fakültesi Bilecik Şeyh Edebali Üniversitesi, Bilecik 5illetişim: nazile.ural@bilecik.edu.tr (https://orcid.org/ 0000-0002-2268-842X) Inşaat Mühendisliği Bölümü, Mühendislik Fakültesi Bilecik Şeyh Edebali Üniversitesi, Bilecik
} 


\title{
Evaluation of Waste Chicken Feather in Soil Improvement
}

\begin{abstract}
The aim of this study is to investigate that the waste chicken feather, which occur in chicken cutting plants, can or can't be used as additive in the improvement of silty soils. It is necessesary that the development and application of new methods to improve the foundation soil because of the inadequate bearing strength and high deformation problems encountered in weak foundation soil. In cases where mechanical improvement is not enough or cannot be used, chemical improvement or the use of wastes can be alternative. In this study, $1 \%$ and $3 \%$ powder waste chicken feather, cut waste chicken feather and full chicken feathers were added to soil and these samples were subjected to standard compaction test and unconfined compression test. As a result of the study, it has been seen that waste chicken feather can be an alternative potential material for expensive geotextiles but it is necessary to increase the number of experiments with different sizes, different ratios and different additives.
\end{abstract}

Keywords- Silt, Waste Chicken Feather, Standart Compaction Test, Unconfined Compression Test, Microstructure 


\section{Gİiș}

Zemin iyileştirmesi, geoteknik mühendisliğinde uzun zamandır uygulanan ve sürekli kullanılan malzeme ve yöntem olarak kendisini yenileyen bir konudur. Eski kaynaklara göre, Babil Tapınağının yapım sürecinde zemin iyileştirmesi yapıldığı ve eski dönemlerde Çinlilerin bambu veya saman çöpü gibi malzemeleri zemin iyileştirmede kullandıkları bilinmektedir [1]. Günümüzde ise tüketimin artması ve hammaddenin azalması sonucunda artan endüstriyel atıkların ekonomiye kazandırılması için bu atıkların geri kazanımının gerekliliğgi görülmektedir. Zemin iyileștirmesi, genel olarak zeminin birim hacım ağırlığının arttırılması, yer altı su seviyesinin düşürülmesi, hidrolik iletkenlik katsayısının istenen düzeye getirilmesi, şişme/büzülme özelliğinin azaltılması ve zeminin dağınık yapısını çeşitli malzemelerin kullanılarak veya kullanılmayarak güçlendirilmesidir. Mevcut zemin özelliklerinin geoteknik mühendisliği açısından uygun olmadığı durumlarda, mekanik veya kimyasal zemin iyileştirme yöntemlerinden birisi kullanılmaktadır. Kimyasal iyileştirmede, katkı maddeleri ile uygun olmayan zemin özelliklerinin uygun hale getirilmesi sağlanmaktadır. Kimyasal katkı maddesi olarak çimento, kireç, uçucu kül, atık cam, atık mermer tozu veya parçaları kullanılmaktadır. Zemin iyileştirme yöntemlerinde atık malzemelerin kullanılmasıyla, doğal çevre kirliliğinin ve ekonomik kaybın azalması sağlanmakta ve doğadaki ham malzemelerin azalmasına engel olunmaktadır. Tavuk çiftliklerinde tüylerin çevreye atılması ve yakılmasının yasaklanmasından dolayı tavuk tüyünün değerlendirilmesi önem kazanmıştır. Türkiye, 2015 yılında yaklaşık 2 milyon ton tavuk eti üretiminde bulunmuştur. Bu değer ile AB ülkelerindeki toplam üretimin \%18'i karşılanmışsa da 200 bin ton tavuk tüyü atığına yol açılmıştır [2]. Bu durum, atıkların hem çevreye hem de insan sağlığına zarar vermeyecek, sürdürülebilir bir şekilde bertaraf edilmesinin daha çok önem kazandığı günümüzde, tavukçuluktan kaynaklanan yüksek miktarlardaki atı̆̆ın ne şekilde bertaraf edileceği sorusunu da beraberinde getirmiştir [3].

Endüstriyel bir atık olarak karşımıza çıkan bu doğal atık malzemesinin miktarının çok olmasından dolayı değerlendirmesi önem arz etmektedir. Atık tavuk tüyü, tavukçuluk üretiminde istenmeyen bir ürün veya malzeme olarak karşımıza çıkmaktadır. İşletmelerde üretim sonrası ortaya çıkan büyük miktarda atık tüyler ciddi katı atık sorununu meydana getirmektedir [4]. Atık tavuk tüyünün yeniden kullanımı ile ilgili az da olsa kristal yapısından dolayı farklı bilim dallarında çalışmalar yapılımışıı. Bu çalışmalardan birisi olan, Ananda Rao vd. (2007) çalışmasında yazarlar tavuk tüyü katkılı epoksi kompozitlerde zayıf eğilme mukavemetini ve gerilme kuvvetini gözlemlemişler ve sonuç olarak aşınma performansının kısa tüy liflerinin takviyesi ile önemli gelişme gösterdiğini söylemişlerdir [5]. Uzun vd. (2011) ağırlıkça artan oranda tavuk tüyü ilavesinin vinil ester, polyester matrikslerin kullanıldığı kompozit malzemelerin mekanik özelliklerine etkisini incelemiş ve lif ilavesinin artan miktarının mekanik özellikleri olumsuz etkilediğini belirlemişlerdir [6]. Zhan ve Wool (2013) yılında epoksi ve tavuk tüyü lifiyle yaptıkları kompozit çalışmasında tavuk tüyü liflerinin yarı kristal yapısı nedeniyle farklı sıcaklıkta eksenel yönde negatif, radyal yönde pozitif bir ısıl genleşme değerine sahip olduğunu belirlemişlerdir [7]. Tavuk tüyünün içerdiği yüksek orandaki keratin, tüyün hidrofobik karakteri kompozit malzemede yoğunluk, termal, termomekanik özelliklere olumlu etki sağlamıştır [8-9]. Atık tavuk tüyü bazı çalışmalarda ise malzemelerin güçlendirmesinde kullanılmıştır [10-14]. Işık vd. (2015) çalışmasında yüksek plastisiteli kil zeminin iyileştirilmesinde, atık tavuk tüyünün kullanılabilirliğini araştırmışlardır. Çalışma kapsamında, atık tavuk tüyü, telek ve tüy lifi olarak $\% 1.0$ ve $\% 2.0$ oranlarında kullanılmıștır. Karışımlardan sonra hazırlanan numuneler 5 ve 10 donma-çözülme çevrim sayısına maruz bırakılmış ve serbest basınç deneyine tabi tutulmuşlardır. Sonuçta, $4 \mathrm{~mm}$ telek kullanılmasının numunelerin serbest basınç mukavemetine olumlu bir etkisinin olmadığ 1 ve $8 \mathrm{~mm}$ telek kullanılan numunelerde ise serbest basınç mukavemet değerinde önemli bir artış olmadığı gözlemlenirken, tüy lifli numunelerin serbest basınç mukavemet değerleri artış göstermiştir [15]. Montes-Zarazúa vd (2015), \%0.25, 0.50, 1.00 ve 3.00 oranlarında tavuk tüyünü kullanarak, zeminlerin şişme özelliklerindeki değişiklikler incelemişlerdir. Ödometrede deney sistemi kullanılarak şişme deneyleri yapılmış ve sonuçta tavuk tüylerinin şişen zeminlerde şişme basıncını azalttığını söylemişlerdir [16].

Bu çalışmada, tavuk tüyleri 3 farklı formda katkı malzemesi olarak kullanılmıştır. Böylelikle, tavuk tüyünün siltin geoteknik özelliklerine etkisi incelenmiş ve farklı oran ve boyutlardaki tavuk tüyünün zemin iyileştirmesinde kullanılabilirliği araştırılmıştır. 


\section{MALZEME}

Kullanılan zemin malzemesi orta plastisiteli silt (MI) olup dane çapı dağılımı Şekil 1'de verilmiştir. Özel bir tavuk üretim firmasından alınan atık tavuk tüyleri, öncelikle yıkanmış ve havada kuruması sağlanmışıır. Atık tavuk tüyleri kurutulduktan sonra tam, yarım ve toz halinde olmak üzere üç farklı şekilde hazırlanmıştır (Şekil 2). Buna göre atık tavuk tüyleri bölgesel bir tavuk işletmesinden alındıktan sonra tüylerin stabil teknik bir malzemeye dönüştürülmesi amacıyla bazı ön işlemler uygulanmıştır; önce çeşme suyunda yıkanmış ve $135{ }^{\circ} \mathrm{C}$ 'de 20 dakika sterilize edilmiş, sonra etüvde $60^{\circ} \mathrm{C}$ 'de 24 saat bekletilerek birinci kurutma, $105{ }^{\circ} \mathrm{C}$ 'de 2 saat bekletilerek ikinci kurutma uygulanmıştır. Daha sonra tavuk tüylerinin mekanik olarak küçük parçalara kesimleri yapılmıştır. Toz olarak kullanılacaklar laboratuvar değirmeninde öğütülmüş, boyutun $0.425 \mu \mathrm{m}$ ve daha küçük olması sağlanmıştır.

Tavuk tüyü lifleri, içi boş ve sert yapida protein lifidir. Bu lifler isıtıldığında çapraz bağlar oluşur ve bu bağlar yapıyı sağlamlaştırmanın yanı sıra yapının daha gözenekli hale dönüşmesini sağlar. Tavuk tüyü diğer lifli malzemelerle benzer özelliklere sahiptir ve özellikle keratin yapıda olmasından dolayı yüne benzer. Selülozik liflerden 6-8 kat daha sağlamdır. Bazı özel uygulama alanlarında yün ve pamuk gibi doğal liflere kıyasla daha üstün özelliklere sahiptir. Liflerin ince olması temas yüzeyinin de daha geniş olmasını sağlar. Islak ortamda bozulmaya karşı dayanımı fazladır, suya doymuş halde bile hacmini koruma eğilimindedir. Kristal yapısından dolayı kararlı ve dayanıklıdır, bu özellikler kullanım alanlarının genişlemesine ve pahalı liflere daha ucuz alternatif oluşturmasını sağlar. Bu özelliklerinden dolayı farklı bilim dallarında çalışmalar yapılmaktadır. İnşaat kompozitlerine uygun olmasından dolayı da bu alanda çalışmalar yapılabilmektedir. Yalıtım ve kaplama amaçlı kullanılması (lambiri ve tavan gibi) kirişlere binen ağırlığı azaltarak yapının yük dayanımını arttırabilir. Endüstri atık sularında yaygın olarak bulunan fenolü emmesiyle bu suların temizlenmesinde kullanılmaktadır. $\mathrm{Bu}$ çalışmada ise toz atık tavuk tüyü geoteknik çalışmalarından birisi olan zemin iyileştirme amaçlı kullanılmışır. Ayrıca, literatürle benzer olarak tavuk tüylerinin yüksek protein içeriğine sahip olduğu belirlenmiştir. Tavuk tüyü lifinin saç, tırnak ve hayvan boynuzlarında bulunan en yüksek miktardaki proteinin, çözünmeyen ve yüksek dayanıklılığa sahip olan keratinden oluştuğu görülmüştür. Keratin bir dizi amino asit içerir, bu amino asitler disülfid veya hidrojen bağları oluşturarak birbirleriyle çapraz bağlanma eğilimindedir. Bu da kompozit yapıya daha sert, güçlü, hafif olma özellikleri yanında iyi termal ve akustik yalıtım özellikleride kazandırabilmektedir [17-19].

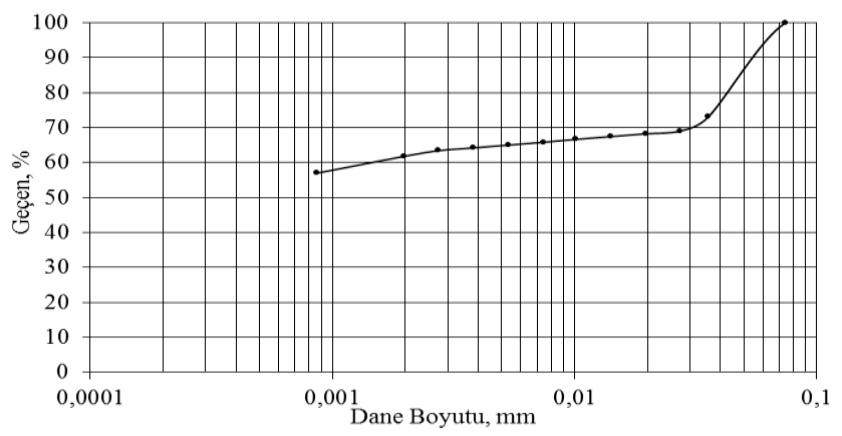

Şekil 1. Siltin dane çapı dağılımı 


\begin{tabular}{|c|c|c|}
\hline & $\begin{array}{l}\text { BŞEÜ Fen Bilimleri Dergisi } \\
7(2), 1196-1205,2020\end{array}$ & $\begin{array}{r}\text { BSEU Journal of Science } \\
\text { DOI: } 10.35193 / \text { bseufbd.489742 }\end{array}$ \\
\hline $\begin{array}{l}\text { BiLECIK SEYY EDEBALI } \\
\text { UNIVERSITESS }\end{array}$ & & 58-7575 (http://dergipark.gov.tr/bseufbd) \\
\hline
\end{tabular}

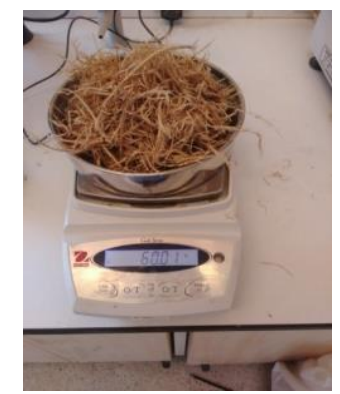

a)

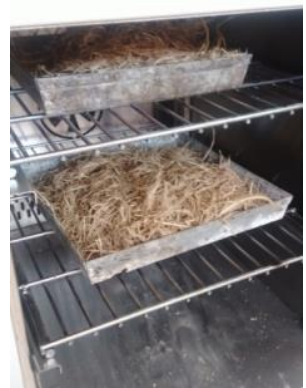

b)

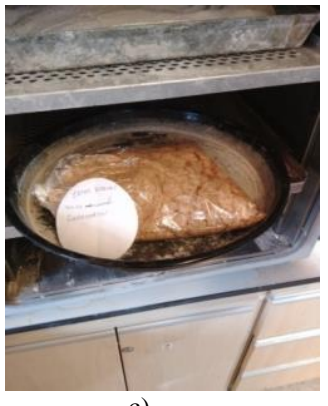

c)

Şekil 2. a) Tam atık tavuk tüyü

b) Kesilmiş atık tavuk tüyü

c) Toz atık tavuk tüyü

\section{YÖNTEM}

Öncelikle siltin likit limit ve plastik limit deneyleri yapılmıştır. Likit limit değeri 42 ve plastik limit değeri 33 olarak bulunmuştur. Tavuk tüylerinin genel kimyasal analizi AOAC (2002) standartlarına göre yapılmıştır [20]. \% nem miktarı gravimetrik yöntemle $105 \pm 5^{\circ} \mathrm{C}$ 'de etüvde bekletilerek AOAC 945.21'e göre, \% kül miktarı gravimetrik yöntemle $550{ }^{\circ} \mathrm{C}$ 'de etüvde bekletilerek AOAC 923.03'e göre, protein miktarı Kjeldahl metoduyla AOAC 962.18' e göre belirlenen toplam azot miktarının 6,25 faktörüyle çarpılmasıyla, \% yağ miktarı sokshlet metoduyla petrol eteri kullanılarak AOAC 920.39'e göre tayin edilmiştir. Tavuk tüyünün genel kimyasal bileşimi Tablo 1'de verilmiştir. Ayrıca tavuk tüyüne ait SEM görüntüsü Zeiss Supra 40VP ile elde edilmiştir (Şekil 3). Çalışma kapsamında, silte \%1 ve \%3 tam, kesilmiş ve toz atık tavuk tüyü eklenerek oluşturulan karışımlar Şekil 4.'de görülmektedir.

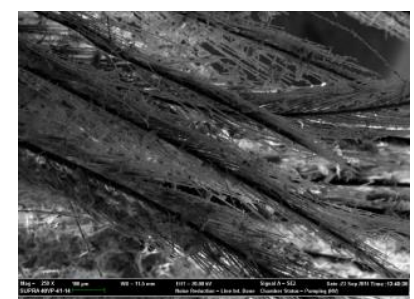

a)

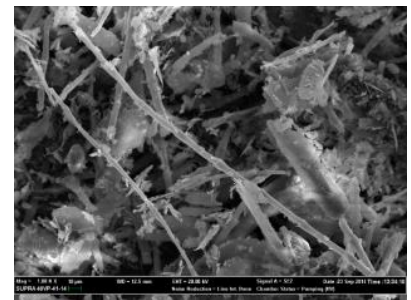

b)

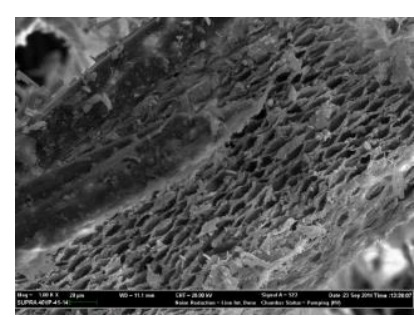

c)

Şekil 3. a) Tavuk tüyünün mikroyapı görüntüsü b) Tüyün bulunduğu iskelet kısmı c) İskeletin peteksi iç dokusu

Tablo 1 Tavuk tüyü genel kimyasal bileşimi

\begin{tabular}{lc}
\hline & $(\%$, Kuru bazda $)$ \\
\hline Ham Protein & $77,00 \pm 0,78$ \\
Ham yağ & $3,95 \pm 0,41$ \\
Kül & $1,85 \pm 0,11$ \\
Nem & $10,94 \pm 0,18$ \\
\hline
\end{tabular}




\begin{tabular}{|c|c|c|}
\hline & $\begin{array}{l}\text { BŞEÜ Fen Bilimleri Dergisi } \\
7(2), 1196-1205,2020\end{array}$ & $\begin{array}{r}\text { BSEU Journal of Science } \\
\text { DOI: } 10.35193 / \text { bseufbd.489742 }\end{array}$ \\
\hline 0 & & 58-7575 (http://dergipark.gov.tr/bseufbd) \\
\hline
\end{tabular}

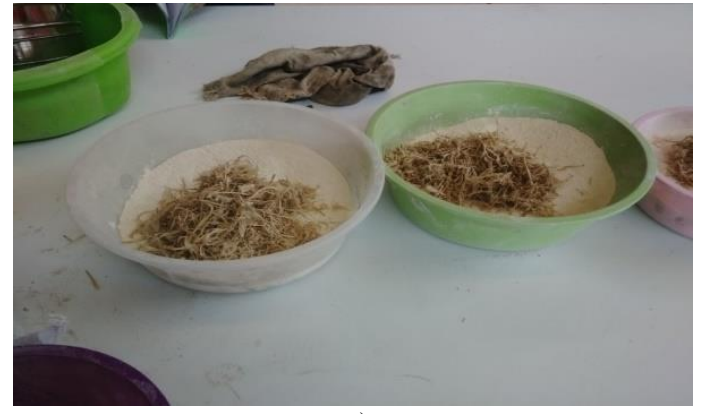

a)

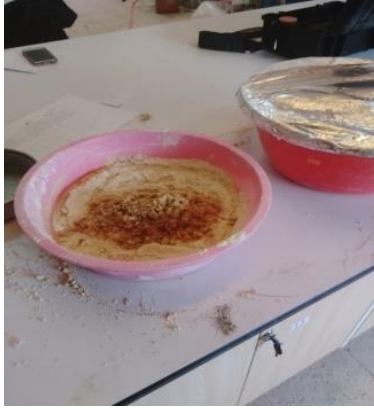

b)

Şekil 4. a) Toz atık tavuk tüyü ve silt b) Kesilmemiş atık tavuk tüyü ve silt

Karışımlar hazırlandıktan sonra ASTM D698 (2012)'ye göre standart kompaksiyon deneyi yapılmıştır (Şekil 5) [21]. Şekil 6.'da siltin standart kompaksiyon deney sonucu elde edilen eğrisi verilmiştir. Tablo 2'de karışımların standart kompaksiyon deney sonucunda elde edilen optimum su muhtevası ve maximum kuru birim hacim ağırlıkları görülmektedir. Atık tavuk tüy miktarının artmasıyla optimum su muhtevasının arttığı, maximum kuru birim hacim ağırlığın ise azaldığı görülmüştür. Fakat tüylerin küçülmesiyle optimum su muhtevalarının daha az arttığı görülmüştür. Optimum su muhtevası ve maximum kuru birim hacim ağırlıkları belirlenen karışımlar serbest basınç deneyine tabi tutulmuştur. Şekil 7.' de numunelerin serbest basınç deneyine hazırlanması görülmektedir. Serbest basınç deneyi ASTM D2166 (2016)'ya göre yapılmıştır [22]. Serbest basınç deney sonuçları Şekil 8'de verilmiştir. Serbest basınç deneylerinde $\% 3$ kesilmiş atık tavuk tüyü ve $\% 3$ tam atık tavuk tüyü ile yapılan deneylerde birim boy kısalması \%20'yi aştığı için deneyler sonlandırılmıştır. \%1 kesilmiş atık tavuk tüyü katkılı numunenin dayanımı \%2 artarken, diğer karışımların dayanımı azalmıştır. Şekil 9'da katkı yüzdelerinin serbest basınca etkisi görülmektedir.

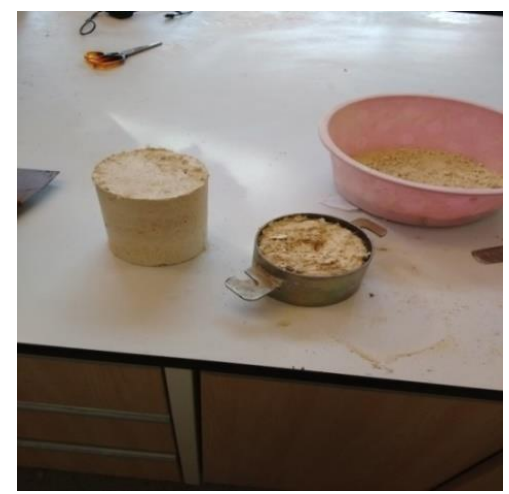

Şekil 5. Kompaksiyon sonrası atık tavuk tüyü ve silt karışımın kompaksiyon kalıbından çıkarılması

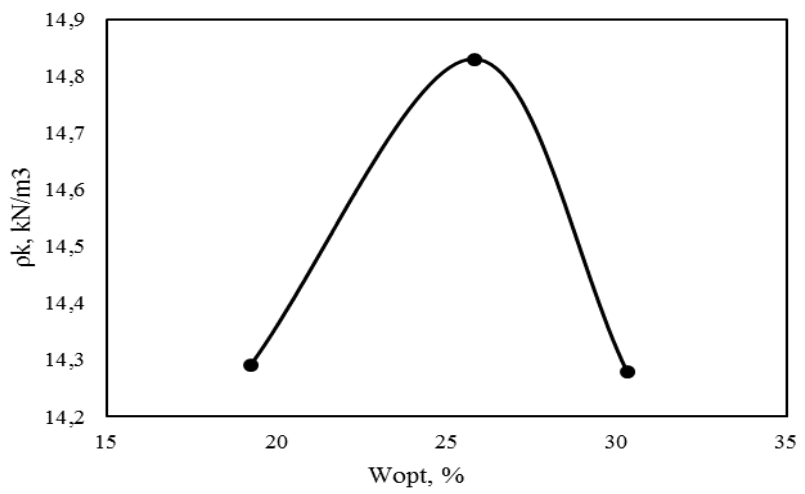

Şekil 6. Siltin standart kompaksiyon deney sonucu 


\begin{tabular}{|c|c|c|}
\hline & $\begin{array}{l}\text { BŞEÜ Fen Bilimleri Dergisi } \\
7(2), 1196-1205,2020\end{array}$ & $\begin{array}{r}\text { BSEU Journal of Science } \\
\text { DOI: } 10.35193 / \text { bseufbd.489742 }\end{array}$ \\
\hline $\begin{array}{l}\text { BiLECIK SEYY EDEBALI } \\
\text { UNIVERSITESS }\end{array}$ & & 58-7575 (http://dergipark.gov.tr/bseufbd) \\
\hline
\end{tabular}

Tablo 2. Standart kompaksiyon deneyi sonuçları

\begin{tabular}{lcc}
\hline \multicolumn{1}{c}{ Numune } & $\begin{array}{c}\mathrm{w}_{\text {opt, }}, \\
\%\end{array}$ & $\begin{array}{c}\rho_{\mathrm{kmax}}, \\
\mathrm{kN} / \mathrm{m}^{3}\end{array}$ \\
\hline Silt & 25 & 14.82 \\
Silt +\%1 Tam Tüy & 30 & 14.15 \\
Silt + \%3 Tam Tüy & 34 & 12.80 \\
Silt + \%1 Kesilmiş Tüy & 28 & 14.17 \\
Silt + \%3 Kesilmiş Tüy & 32 & 13.62 \\
Silt + \%1 Toz Tüy & 25 & 14.52 \\
Silt +\%3 Toz Tüy & 28 & 13.75 \\
\hline
\end{tabular}

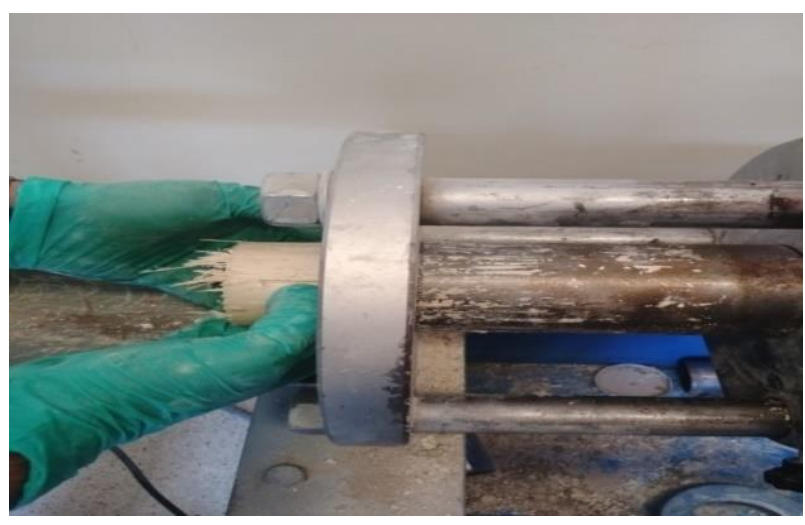

Şekil 7. Numunenin çıkarılması
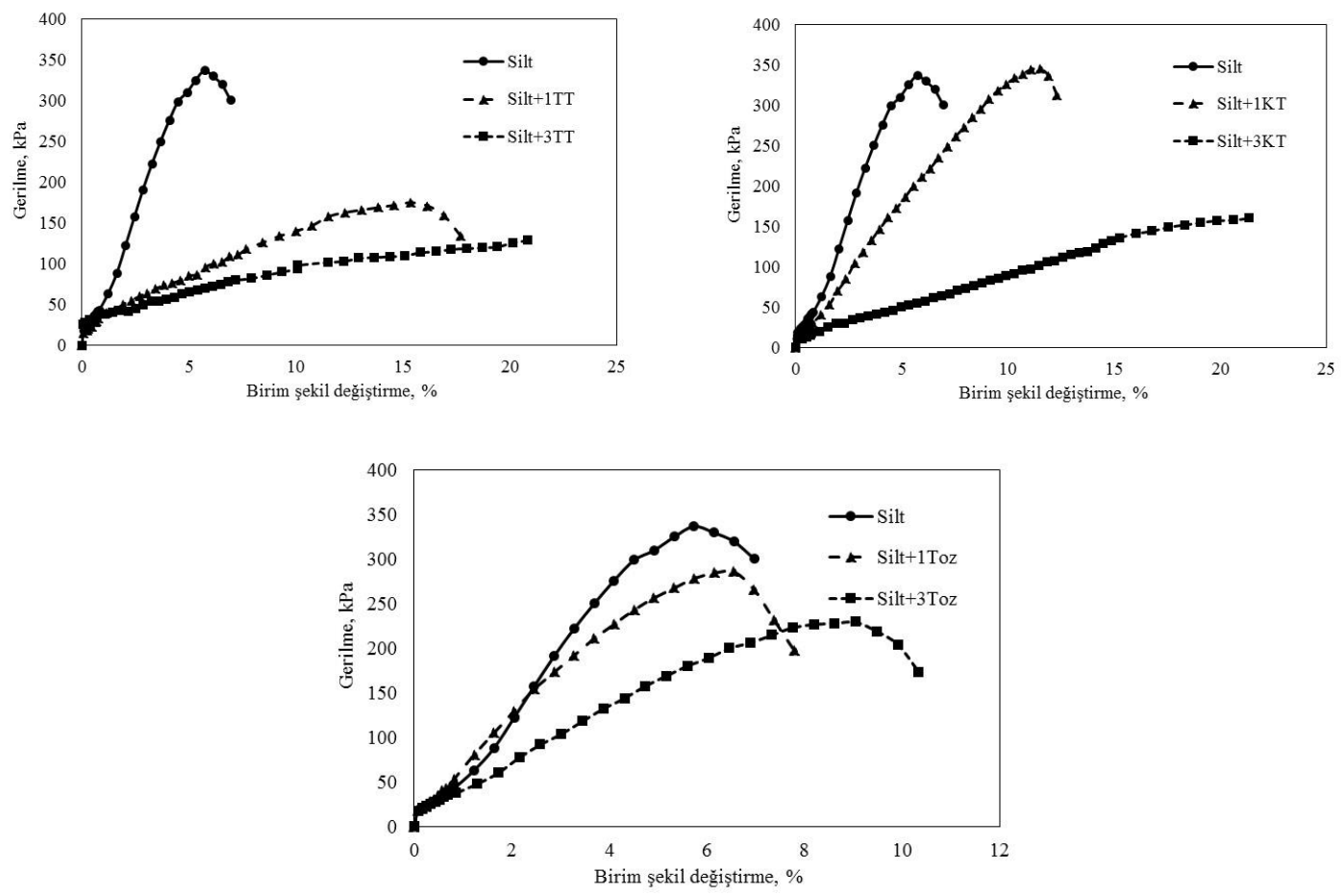

Şekil 8. Karışımların serbest basınç dayanım eğrileri 


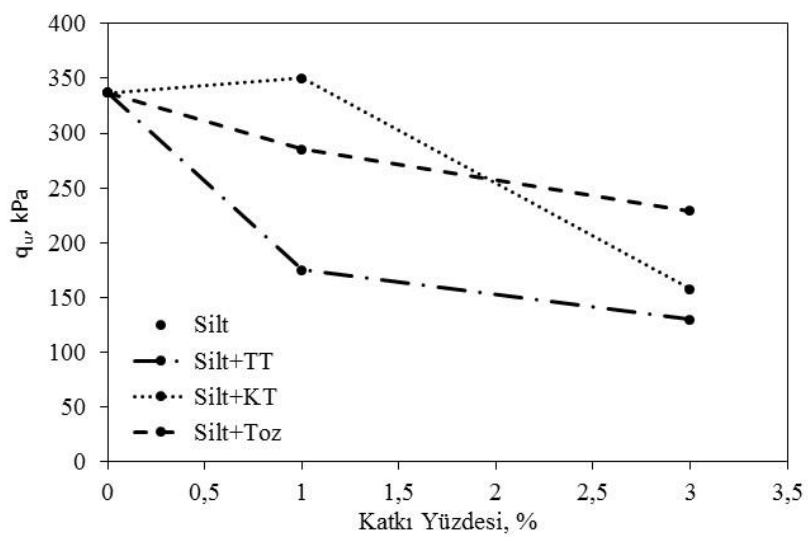

Şekil 9. Katkı yüzdelerinin serbest basınç dayanımına etkisi

\section{SONUÇLAR}

Bu çalı̧̧mada, atık tavuk tüyü silte toz, kesilmiş ve tam olmak üzere $\% 1$ ve $\% 3$ oranlarında eklenerek, zeminlerin serbest basınç dayanımında doğal lif olarak kullanılan atık tavuk tüylerinin etkisi incelenmiştir. Bu amaçla öncelikle standart kompaksiyon deneyleri yapılmış ve atık tavuk tüy miktarının artmasıyla optimum su muhtevasının arttı̆̆ı, atık tavuk tüylerinin boyutlarının küȩülmesiyle optimum su muhtevalarının daha az arttı̆g görülmüştür. Standart kompaksiyon deneyi ile hazırlanan numuneler üzerinde yapılan serbest basınç deney sonuçlarından, \%1 kesilmiş atık tavuk tüyü katkılı numunenin dışındaki tüm karışımlarda serbest basınç dayanımının azaldığı ve daha farklı yüzdelerde, boyutlarda ve biçimlerde deney sayısının arttırılmasının gerekliliği görülmüştür. Sonuç olarak, atık tavuk tüyünün pahalı liflere alternatif potansiyel malzeme olabileceği görülmüş fakat atık tavuk tüyünün zemin iyileştirmede kullanılabilirliğinin daha net belirlenebilmesi için daha farklı boyutta, farklı oranlarda ve farklı katkı malzemeleriyle deney sayısının arttırılmasının gerekliliği görülmüştür.

\section{KAYNAKLAR}

[1] Van Impe, W. E., "Soil improvement techniques and their evaluation", Balkema, Rotterdam, Nertherlands, 1989.

[2] Türkiye İstatistik Kurumu website, Haber Bülteni - Kümes Hayvancıllğı Üretimi, [Online]. Available: http://www.tuik.gov.tr/basinOdasi/haberler/2016_40_20160330.pdf., 2016.

[3] Sarı Ö.F., Özdemir, S., Tavuk Kesimhane Atıklarının Yönetimi ve Alternatif Değerlendirme Yöntemleri, Sakarya Ticaret Borsası website, [Online]. Available: https://www.stb.org.tr/Dosyalar/Arastirmalar/tavukkesimhane-atiklarinin-yonetimi.pdf., 2018.

[4] Bartels, T., "Variations in the morphology, distribution, and arrangement of feathers in domesticated birds", Journal of Experimental Zoology Part B: Molecular and Developmental Evolution, vol. 298(1), pp. 91-108, 2003.

[5] Rao, A., V., Satapathy, A. ve Mishra, S. C., "Polymer Composites Reinforced with Short Fibers Obtained from Poultry Feathers", Proceedings of International and INCCOM-6 Conference Future Trends in Composite Materials and Processing, Indian Institute of Technology, Kanpur, 2007.

[6] Uzun, M., Sancak, E., Patel, I., Usta, I., Akalin, M. ve Yuksek, M., "Mechanical Behaviour of Chicken Quills and Chicken Feather Fibres Reinforced Polymeric Composites", Archives of Materials Science and Engineering, vol. 52(2): pp. 82-86, 2011. 
[7] Zhan M. ve Wool R.P., "Thermal Expansivity of Chicken Feather Fiber Reinforced Epoxy Composites", Journal of Applied Polymer Science, vol. 128(2), pp. 997-1003, 2013.

[8] Flores-Hernández, C. G, Colín-Cruz, A., Velasco-Santos, C., Castaño, V. M., Rivera-Armenta J. L., Almendarez-Camarillo, A., García-Casillas, P. E. ve Martínez-Hernández, A. L., "All green composites from fully renewable biopolymers: Chitosan-starch reinforced with keratin from feathers", Polymers, vol. 6(3), pp. 686-705, 2014.

[9] Jimenez-Cervantes Amieva, E., Velasco-Santos, C., Martinez-Hernandez, A. L., Rivera-Armenta, J. L., Mendoza-Martinez, A. M. ve Castano, V. M., "Composites from Chicken Feathers Quill and Recycled Polypropylene", Journal of Composite Materials, vol. 49(3), pp. 275-283, 2014.

[10] Dweib, M. A., Bullions, T. A., Loss, A. C. ve Wool, R. P., "Recycled Newspaper and Chicken Feathers as Reinforcement Fiber in Bio-Composite Materials", Proc. Annual Technical Conference - ANTEC, pp. 1478-1482, 2004.

[11] Acda, M. N., "Waste chicken feather as reinforcement in cement-bonded composites", Philippine Journal of Science, vol. 139(2), pp. 161-166, 2010.

[12] Uzun, M., Sancak, E., Patel, I., Usta, I., Akalın, M. ve Yuksek, M., "Mechanical behaviour of chicken quills and chicken feather fibres reinforced polymeric composites", Archives of Materials Science and Engineering, vol. 52(2), pp. 82-86, 2011.

[13] Subramani, T., Krishnan, S., Ganesan, S. K. ve Nagarajan, G., "Investigation of mechanical properties in polyester and phenylester composites reinforced with chicken feather fiber", International Journal of Engineering Research and Applications, 1(4), 93-104, 2014.

[14] Amieva, E. J-C., Velasco-Santos, C., Martinez-Hernandez, A. L., Rivera-Armenta, J. L., MendozaMartinez, A. M. ve Castan, V. M., "Composites from chicken feathers quill and recycled polypropylene", Journal of Composite Materials, vol. 49(3), pp. 275-283, 2015.

[15] Işık, F., Akbulut R. K., Zaimoğlu, A. Ş. ve Arasan, S., "Kil Zeminlerin İyileştirmesinde Atık Doğal Liflerin Kullanabilirliği”, 6. Geoteknik Sempozyumu, Çukurova Üniversitesi, Adana, 2015.

[16] Montes-Zarazua E., Colin-Cruz A., Perez-Rea M. D., de Icaza M., Velasco-Santos C., Martinez-Hernandez A. L., "Effect of Keratin Structures from Chicken Feathers on Expansive Soil Remediation", Advances in Materials Science and Engineering, vol. 2015, Article ID 907567, 10 pages, 2015.

[17] Schmidt, W. F., "Innovative feather utilization strategies", Proc. National Poultry Waste Management Symposium, Auburn University Printing Services, pp. 276-282, 1998.

[18] Acda, M. N. "Waste Chicken Feather as Reinforcement in Cement-Bonded Composites", Philippine Journal of Science, vol. 139, pp. 161-166, 2010.

[19] Tseng, F.C.J, Verbeek, C.J.R. "Biofibre production from chicken feather", Proc. SCENZI Chemical Annual Conference 2011, New Zealand, 2011.

[20] AOAC, "Official Methods of Analysis of the Association of Official Analytical Chemists", 17th Ed., Editor; William Horwitz, 2002.

[21] ASTM D 698, "Standard Test Methods for Laboratory Compaction Characteristics of Soil Using Standard Effort", Annual book of ASTM Standards, vol. 15.09, West Conshohocken PA, 2012. 


\begin{tabular}{|c|c|c|}
\hline & $\begin{array}{l}\text { BŞEÜ Fen Bilimleri Dergisi } \\
7(2), 1196-1205,2020\end{array}$ & $\begin{array}{r}\text { BSEU Journal of Science } \\
\text { DOI: } 10.35193 / \text { bseufbd.489742 }\end{array}$ \\
\hline & & 58-7575 (http://dergipark.gov.tr/bseufbd) \\
\hline
\end{tabular}

[22] ASTM D 2166, "Standard Test Method for Unconfined Compressive Strength of Cohesive Soil", Annual book of ASTM Standards, vol. 4.08, West Conshohocken PA, 2016. 